\title{
Aktivitas Antibakteri Sabun Cuci Tangan yang Mengandung Ekstrak Metanol Rumput Laut Eucheuma spinosum (Antibacterial Activity Test of Eucheuma spinosum Methanol Extract Hand Wash)
}

\author{
Nur I. Akib ${ }^{1}$, Mariani Triwatami ${ }^{1}$, Andi E.P. Putri ${ }^{2}$ \\ ${ }^{1}$ Fakultas Farmasi, Universitas Halu Oleo, Kendari \\ ${ }^{2}$ Biologi Farmasi, Sekolah Tinggi Ilmu Farmasi, Makassar \\ Corresponding Author E-mail: nurilliyyinakib@gmail.com
}

\begin{abstract}
Background: Eucheuma spinosum seaweed contain flavonoid, triterpenoid, alkaloids and polyphenol which has been widely used in antibacterial activity. Purpose(s):The aim of the research are to determine antibacterial activities of metanol extracts of E. spinosum against Staphylococcus aureus ATCC 25923 and Escherichia coli ATCC 25922; to formulate hand wash of seaweed of methanol extract E. spinosum that has antibacterial activity and has physical and chemical stability. Methods: Seaweed E.spinosum methanol extract was derived by maceration method. Antibacterial activities of the extract were tested by liquid dilution and solid dilution method. Hand wash was formulated by mechanical dissolved methods. Antibacterial activity of hand wash were tested by liquid dilution and solid dilution method. Physical and chemical stabilities were conducted by cycling test. Results:. These were showed through minimum inhibitory concentration (MIC) of ethanol extracts of E. spinosum against S. aureus ATCC 25923 at concentrations of 6\% and E. coli ATCC 25922 at concentrations of $6 \%$. The minimum bactericidal concentration $(M B C)$ of ethanol extracts of $E$. spinosum against S. aureus ATCC 25923 at concentrations of 8\% and E. coli ATCC 25922 at concentrations of $8 \%$. Formulation of hand wash seaweed E. spinosum methanol extract at concentrations of $8 \%$ and $10 \%$. The test of stabilities results of hand wash changes were organoleptic, viscosity, $\mathrm{pH}$, and foaming ability were accordance to qualified standard. The antibacterial activity of hand wash contains seaweed E. spinosum methanol extract at concentration of 8\% and 10\% have bactericidal activity againts S. aureus ATCC 25923 and E. coli ATCC 25922. Conclusion: Overall, these results suggested that formula of hand wash contains E. spinosum metanol extracts have antibacterial properties against S. aureus ATCC 25923 and E. coli ATCC 25922.
\end{abstract}

Keywords: antibacterial, Eucheuma spinosum, hand wash, physical and chemical stability

\begin{abstract}
ABSTRAK
Latar Belakang: Rumput laut Eucheuma spinosum mengandung flavonoid, triterpenoid, alkaloid, dan polifenol yang memiliki aktivitas antibakteri. Tujuan: Penelitian ini bertujuan mengetahui aktivitas antibakteri ekstrak metanol E. spinosum terhadap Staphylococcus aureus ATCC 25923 and Escherichia coli ATCC 25922; membuat sediaan sabun cuci tangan dari ekstrak metanol E. spinosum yang memiliki aktivitas antibakteri dan stabil secara fisika dan kimia. Metode: Ekstrak metanol E. spinosum diperoleh dengan metode maserasi. Uji aktivitas antibakteri ekstrak dilakukan dengan metode dilusi cair dan dilusi padat. Sabun cuci tangan diformulasi dengan metode pencampuran mekanik. Uji aktivitas antibakteri sabun cuci tangan dilakukan dengan metode dilusi cair dan dilusi padat. Uji stabilitas fisika kimia dilakukan dengan metodecycling test. Hasil: Konsentrsi Hambat Minimum (KHM) ekstrak metanol E. spinosum terhadap S. aureus ATCC 25923 adalah 6\% dan terhadap E. coli ATCC 25922 adalah 8\%. Ekstrak metanol E. spinosum dapat diformulasi menjadi sabun cuci tangan dengan konsentrasi $8 \%$ dan 10\%. Uji stabilitas menunjukkan bahwa perubahan organoleptik, viskositas, $\mathrm{pH}$, dan kemampuan membentuk busa masih berada dalam nilai yang dipersyaratkan. Uji aktivitas antibakteri sabun cuci tangan yang mengandung ekstrak metanol E. spinosum dengan konsentrasi 8\% dan 10\% memiliki aktivitas antibakteri terhadap ATCC 25923 and
\end{abstract}


E. coli ATCC 25922. Simpulan: Formula sabu cuci tangan yang mengandung ekstrak metanol E. spinosum memiliki aktivitas antibakteri terhadap ATCC 25923 and E. coli ATCC 25922.

Kata kunci: antibakteri, Eucheuma spinosum, sabun cuci tangan, stabilitas fisika kimia

\section{PENDAHULUAN}

Penyakit infeksi merupakan salah satu masalah kesehatan terbesar dan merupakan salah satu penyebab utama kematian di dunia. Selain virus, bakteri juga menyebabkan penyakit infeksi. Staphylococcus aureus dan Escherichia coli merupakan bakteri patogen yang paling banyak menyerang manusia. Bakteri dapat masuk ke dalam tubuh manusia melalui telapak tangan, hidung, mulut, sistem pencernaan, dan saluran urin atau organ genital (Poolman, 2018).

Beberapa penyakit yang disebabkan oleh $S$. aureus antara lain, osteomielitis, abses otak, bakteremia, endokarditis, pneumonia, dan infeksi gastroenteritis. Selain Sedangkan penyakit infeksi yang disebabkan oleh bakteri E. coli antara lain, infeksi saluran kemih, peritonitis akut, traveler's diarrhea, meningitis, pneumonia, dan sepsis neonatus (WHO, 2006).

Kulit adalah organ terluar tubuh yang membutuhkan perlindungan terhadah mikroorganisme patogen. Menjaga kebersihan tangan penting dilakukan untuk melindungi tubuh dari infeksi bakteri. Cara yang paling sederhana untuk menjaga kebersihan tangan adalah dengan mencuci tangan menggunakan sabun antiseptik dan air (Joy dkk., 2012).

Sabun merupakan bahan yang dapat mengemulsi air dan minyak. Penggunaan sabun efektif mengangkat kotoran yang menempel pada permukaan kulit, baik yang larut dalam air maupun dalam lemak. Sabun antiseptik memiliki bahan aktif antibakteri untuk menghambat sampai menghentikan pertumbuhan bakteri (Deiner, 2008).

Banyak produk sabun antiseptik yang menggunakan bahan aktif kimia sintesis tetapi memiliki beberapa efek samping. Penggunaan sabun cuci tangan (hand wash) yang berulang-ulang dapat menyebabkan iritasi kulit, kulit kering, ruam, dan resistensi bakteri (Patil dkk., 2015). Salah satunya telah diteliti yaitu Sabun cuci tangan dari ekstrak daun sirih hutan yang mengandung senyawa kelompok alkaloid, fenil propaniod, terpen, dan steroid terbukti lebih lebih efektif dalam melindungi kulit dari mikroorganisme yang berbahaya (Alea, 2019) Indonesia merupakan negara maritim dengan lebih dari 70\% permukaannya didominasi oleh lautan. Indonesia memiliki panjang pantai sekitar $81.000 \mathrm{~km}$ dengan sumber daya hayati pesisir dan laut yang dapat dimanfaatkan secara ekonomis sebagai bahan makanan, bahan dasar obat, dan bahan dasar kosmetik (Anonim, 2014).

Kabupaten Wakatobi, Provinsi Sulawesi Tenggara merupakan Kawasan Taman Nasional dengan luas 1.390 .000 Ha, yang terdiri dari 97\% lautan dan 3\% daratan. Hal ini menyebabkan masyarakat Wakatobi banyak memanfaatkan sumber daya laut, termasuk untuk pengobatan. Salah satu tumbuhan yang secara tradisional digunakan masyarakat Wakatobi sebagai obat (antibakteri) adalah rumput laut jenis Eucheuma spinosum (Coremap, 2001).

Rumput laut Eucheuma spinosum memiliki metabolit sekunder yaitu 
flavonoid, alkaloid, saponin, dan tannin (Safitri, 2018) karena kondisi lingkungan hidupnya yang ekstrim seperti salinitas yang tinggi atau digunakan untuk mempertahankan diri dari ancaman predator. Senyawa bioaktif tersebut memiliki aktivitas antibakteri yang memungkinkan dapat menghambat pertumbuhan bakteri patogen pada manusia (Siregar dkk., 2005).

Berdasarkan latar belakang tersebut, penulis berinisiatif mengembangkan suatu produk dengan memanfaatkan senyawa bioaktif yaitu flavonoid, alkaloid, saponin, dan tannin yang terkandung dalam rumput laut Eucheuma spinosum asal di perairan Wakatobi dalam bentuk sabun handwash. Penelitian ini bertujuan memperoleh formula sediaan hand wash yang mengandungekstrak metanol rumput laut E. spinosum yang memiliki aktivitas sebagai antibakteri.

\section{METODE}

\section{Bahan}

Rumput laut Eucheuma spinosum, metanol, gliserin, metil paraben, natrium lauril sulfat, N- CMC, dinatrium-EDTA, minyak lemon, sunset yellow, alkohol, air suling, botol plastik kosmetik, kasa steril, kapas steril, kertas saring, aluminium foil, media Nutrient Agar $\left(\right.$ Merck $^{\circledR}$ ), media Nutrient Broth $\left(\right.$ Merck $^{\circledR}$ ), NaCl fisiologis 0,9\% (Otsuka ${ }^{\circledR}$ ), triklosan, isolat Bakteri Staphylococcus aureus ATCC 25923 dan Escherichia coli ATCC 25922.

Alat

Rotary vacuum evaporator (BuciR-210 ${ }^{\circledR}$ ), autoklaf (Presto ${ }^{\circledR}$ ), inkubator $\left(\mathrm{Memmert}^{\circledR}\right.$ ), hot plate (MS-H280$\left.\mathrm{PRO}^{\circledR}\right)$, timbangan analitik $\left(\mathrm{HWH}^{\circledR}\right)$, lemari pendingin $\left(\right.$ Sharp $\left.^{\circledR}\right)$, blender dry mill (Philips ${ }^{\circledR}$ ), lampu spritus, laminar air flow $\left(\right.$ Chuaire $^{\circledR}$ ), pipet mikro (Socorex ${ }^{\circledR}$ ), rak tabung, ose bulat, ose lurus, pinset, filler, pipet ukur (Pyrex ${ }^{\circledR}$ ), pipet tetes, labu Erlenmeyer $500 \mathrm{ml}$ (Pyrex ${ }^{\circledR}$ ), cawan petri, tabung reaksi(Pyrex ${ }^{\circledR}$ ), gelas kimia 250 $\mathrm{mL} \quad\left(\right.$ Pyrex $\left.^{\circledR}\right)$, gelas ukur $1000 \mathrm{~mL}$ $\left(\right.$ Pyrex $\left.^{\circledR}\right), \quad$ mixer $\quad\left(\right.$ Miyako $\left.{ }^{\circledR}\right), \quad$ pH-meter $\left(\right.$ Jenway $^{\circledR}$ ), dan viskometer (Rion ViskometerVT-04F ${ }^{\circledR}$ ).

\section{Pengolahan sampel}

Rumput laut Eucheuma spinosum diperoleh dari Desa Ambeua Kec. Kaledupa Kabupaten Wakatobi. Sampel disortasi basah, dicuci, dirajang, dan dikeringkan menggunakan oven $\left(40^{\circ} \mathrm{C}\right)$, kemudian dihaluskan menjadi serbuk kering.

\section{Proses Ekstraksi}

Sebanyak 1,46 kg serbuk kering dimaserasi dengan pelarut metanol $3 \mathrm{~L}$ dalam wadah kaca tertutup selama 3 x 24 jam. Maserat disaring dan filtratnya diuapkan menggunakan rotary vacuum evaporator $\left(60^{\circ} \mathrm{C}\right)$, diuapkan dalam water bath hingga diperoleh ekstrak kental, dan dihitung rendemen ekstrak.

\section{Pembuatan Suspensi Bakteri Uji}

Sebanyak 1 ose bakteri uji disuspensikan dalam $2 \mathrm{~mL} \quad \mathrm{NaCl}$ 0,9\%,dihomogenkan menggunakan vortex, diukur absorbansi pada panjang gelombang $625 \mathrm{~nm}$. Suspensi bakteri ditandai dengan adanya kekeruhan pada $\mathrm{NaCl}$ 0,9\% dengan nilai absorbansi 0,205. Kekeruhan bakteri disesuaikan dengan standar McFarland 0,5 yang setara dengan kepadatan bakteri 150 x 106 CFU/ml (Paju dkk., 2013). 
Tabel 1. Formula sediaan hand wash

\begin{tabular}{cccc}
\hline \multirow{2}{*}{ Nama bahan } & \multicolumn{2}{c}{ Konsentrasi } & \multirow{2}{*}{ Kegunaan } \\
\cline { 2 - 3 } & A & B & Zat aktif \\
\hline Ekstrak metanol E. spinosum & $8 \%$ & $10 \%$ & Surfaktan dan pembentuk busa \\
\hline Natrium lauril Sulfat & $3 \%$ & $3 \%$ & Pengawet \\
\hline Metil paraben & $0,1 \%$ & $0,1 \%$ & Pengatur viskositas \\
\hline Na-CMC & $1,2 \%$ & $1,2 \%$ & Pumektan \\
\hline Gliserin & $5 \%$ & $5 \%$ & Pengkhelat \\
\hline Dinatrium-EDTA & $0,1 \%$ & $0,1 \%$ & Pewarna \\
\hline Minyak lemon & 2 tetes & 2 tetes & Pelarut \\
\hline Sunset yellow & 1 tetes & 1 tetes & \\
\hline Air suling & $82,6 \%$ & $80,6 \%$ &
\end{tabular}

\section{Penentuan KHM dan KBM Ekstrak}

Sebanyak 0,5 mL suspensi bakteri uji dimasukkan ke dalam 6 tabung reaksi berisi 3-5 mL media NB steril. Selanjutnya dimasukkan $0,5 \mathrm{~mL}$ ekstrak dengan konsentrasi yang berbeda yaitu 4\%, 6\%, $8 \%$, dan $10 \%$, metanol (K-) dan triklosan $1 \%(\mathrm{~K}+)$. Tabung reaksi ditutup, digojog, didiamkan (15 menit), diinkubasi (24 jam; $37^{\circ} \mathrm{C}$ ), lalu diamati tingkat kejernihannya (Fatisa, 2013).

\section{Uji Penegasan KHM dan KBM Ekstrak}

Diambil1 ose dari masing-masing tabung reaksi dari uji sebelumnya digoreskan pada NA steril, didiamkan 15 menit, diinkubasi (24 jam; $\left.37^{\circ} \mathrm{C}\right)$, lalu diamati pertumbuhan bakteri di sekitar goresan (Fatisa, 2013).

\section{Formulasi Handwash}

Natrium lauril sulfat, metil paraben, dinatrium-EDTA dilarutkan dalam air suling $\left(50^{\circ} \mathrm{C}\right)$. Lalu ditambahkan Na-CMC yang telah dikembangkan menggunakan air panas. Lalu ditambahkan ekstrak metanol E. spinosum yang telah dilarutkan dalam gliserin. Lalu ditambahkan minyak lemon dan sunset yellow secukupnya. Lalu ditambahkan air suling hingga $100 \mathrm{~mL}$ dan diaduk hingga homogen (Pal dkk., 2015).

\section{Penentuan KHM dan KBM Hand Wash}

Sebanyak 0,5 mL suspensi bakteri uji dimasukkan ke dalam 4 tabung reaksi berisi 3-5 mL media NB steril. Selanjutnya dimasukkan 0,5 $\mathrm{mL}$ sediaan formula $\mathrm{A}$, formula $\mathrm{B}$, hand wash lifebuoy ${ }^{\circledR}(\mathrm{K}+)$, dan basis sediaan (K-). Tabung reaksi ditutup, digojog, didiamkan (15 menit), diinkubasi (24 jam; $37^{\circ} \mathrm{C}$ ), lalu diamati tingkat kejernihannya (Fatisa, 2013).

\section{Uji Penegasan KHM dan KBM Hand Wash}

Diambil1 ose dari masing-masing tabung reaksi dari uji sebelumnya dan digoreskan pada NA steril, didiamkan 15 menit, diinkubasi $\left(24\right.$ jam; $\left.37^{\circ} \mathrm{C}\right)$, lalu diamati pertumbuhan bakteri di sekitar goresan (Fatisa, 2013).

\section{Uji Stabilitas Fisik Hand Wash}

sediaan disimpan dalam lemari pendingin $\left(4^{\circ} \mathrm{C} ; 24\right.$ jam $)$ kemudian dipindahkan ke dalam oven $\left(40^{\circ} \mathrm{C} ; 24\right.$ jam). Perlakuan tersebut dihitung sebagai 1 siklus dan diulangi sebanyak 6 siklus. Perubahan fisik diamati sebelum dan sesudah cycling test meliputi pemeriksaan organoleptik, pengukuran $\mathrm{pH}$ menggunakan pH-meter, pengukuran viskositas menggunakan viskometer, dan kemampuan membentuk busa 
menggunakan vortexs (2 menit) lalu dihitung tinggi busanya.

\section{HASIL}

Tabel 2. PenentuanKHM dan KBM ekstrak terhadap bakteri

\begin{tabular}{ccc}
\hline Konsentrasi & S. aureus & E. coli \\
\hline $4 \%$ & Keruh & Keruh \\
\hline $6 \%$ & Jernih & Jernih \\
\hline $8 \%$ & Jernih & Jernih \\
\hline $10 \%$ & Jernih & Jernih \\
\hline Kontrol (+) & Jernih & Jernih \\
\hline \multirow{2}{*}{ Kontrol (-) } & Sangat & Sangat \\
& Keruh & Keruh \\
\hline
\end{tabular}

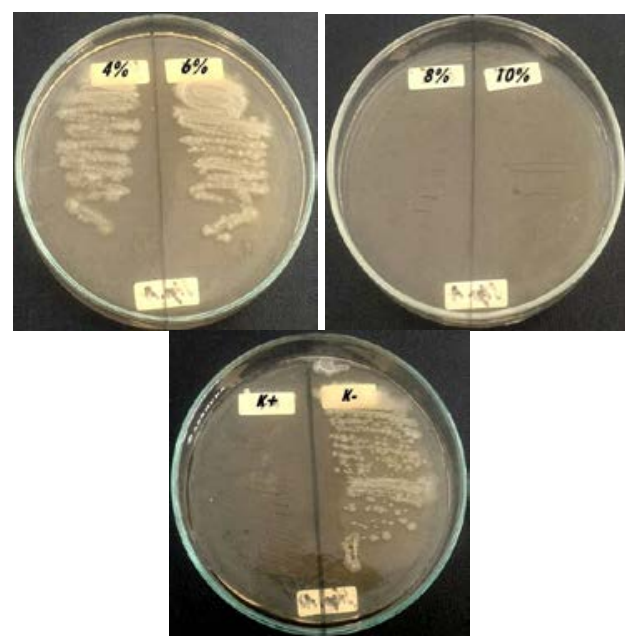

Gambar 1. Hasil uji penegasan KHM dan KBM ekstrak terhadap bakteri S. aureus

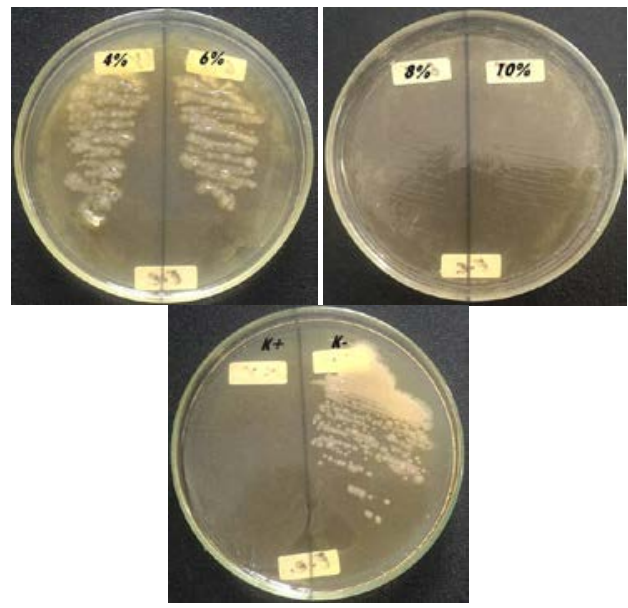

Gambar 2. Hasil uji penegasan KHM dan KBM ekstrak terhadap bakteri E. coli

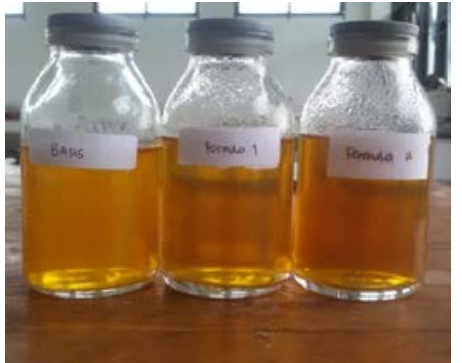

Gambar 3. Sediaan hand wash

Tabel 3. PenentuanKHM dan KBM hand wash terhadap bakteri

\begin{tabular}{ccc}
\hline Perlakuan & S. aureus & E. coli \\
\hline $\mathrm{A}$ & Jernih & Jernih \\
\hline $\mathrm{B}$ & Jernih & Jernih \\
\hline $\mathrm{K}+$ & Jernih & Jernih \\
\hline $\mathrm{K}-$ & Jernih & Keruh \\
\hline
\end{tabular}

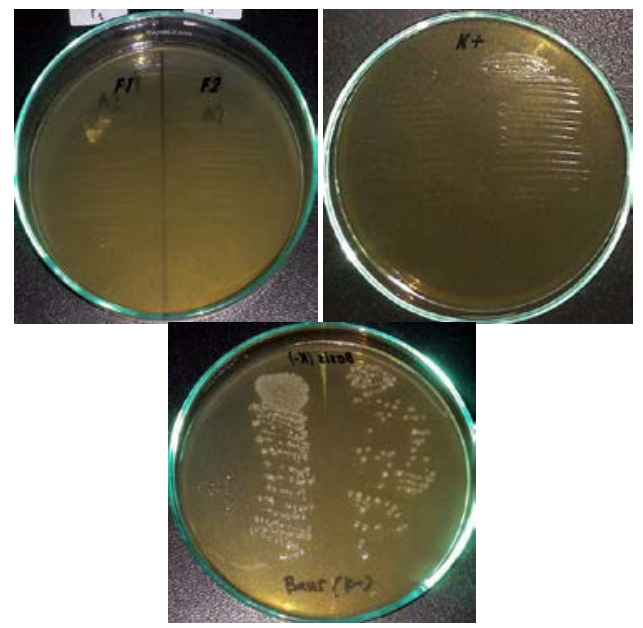

Gambar 4. Hasil uji penegasan hand wash terhadap bakteri $S$. aureus

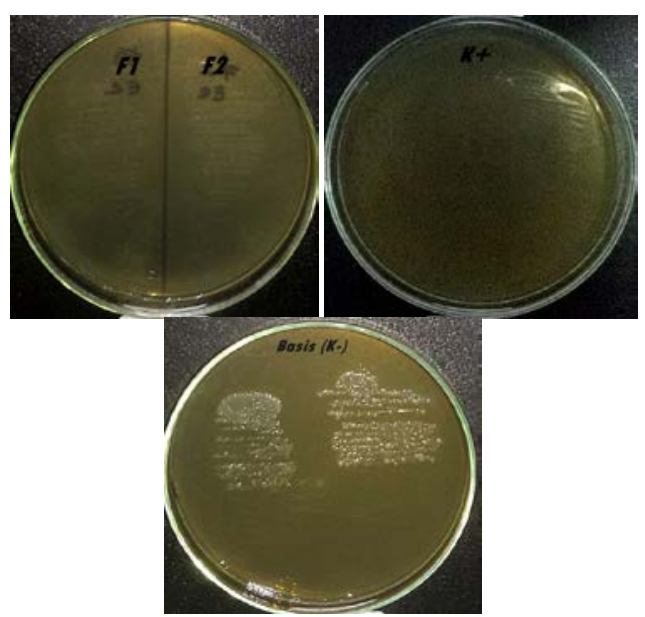

Gambar 5. Hasil uji penegasan hand wash terhadap bakteri E. coli 
Tabel 4. Stabilitas organoleptik hand wash

\begin{tabular}{cccc}
\hline Formula & Cycling test & Warna & Bau \\
\hline \multirow{2}{*}{ Basis } & Sebelum & Oranye muda, jernih & Lemon \\
\cline { 2 - 4 } & Sesudah & Oranye muda, jernih & Lemon \\
\hline \multirow{2}{*}{ A } & Sebelum & Oranye tua, jernih & Lemon \\
\cline { 2 - 4 } & Sesudah & Oranye tua, jernih & Lemon \\
\hline \multirow{2}{*}{ B } & Sebelum & Oranye tua, jernih & Lemon \\
\cline { 2 - 4 } & Sesudah & Oranye tua, jernih & Lemon \\
\hline
\end{tabular}

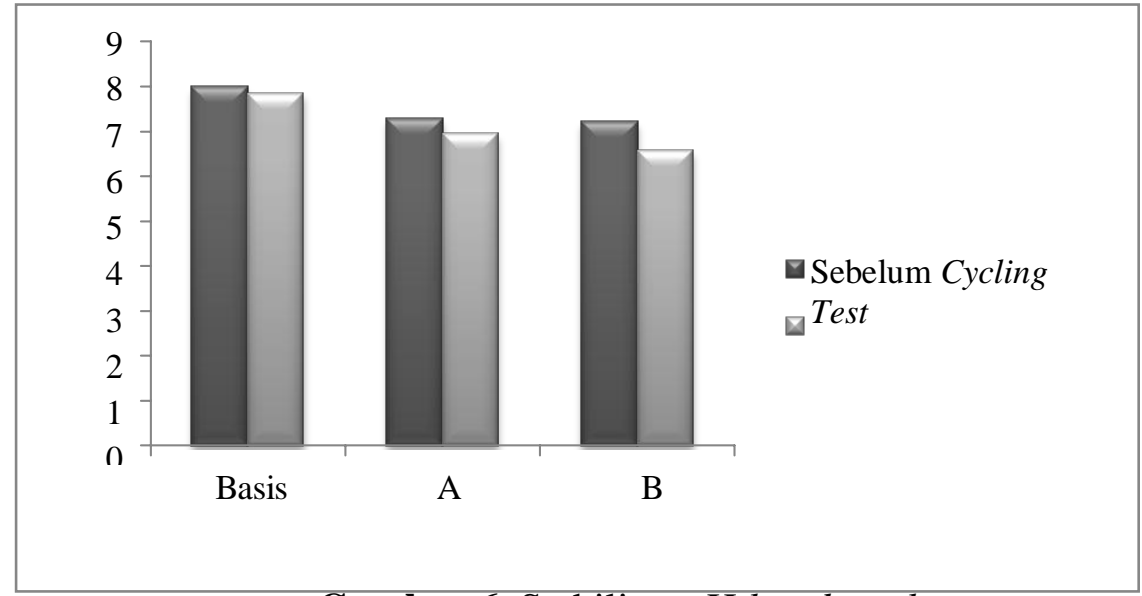

Gambar 6. Stabilitas $\mathrm{pH}$ hand wash

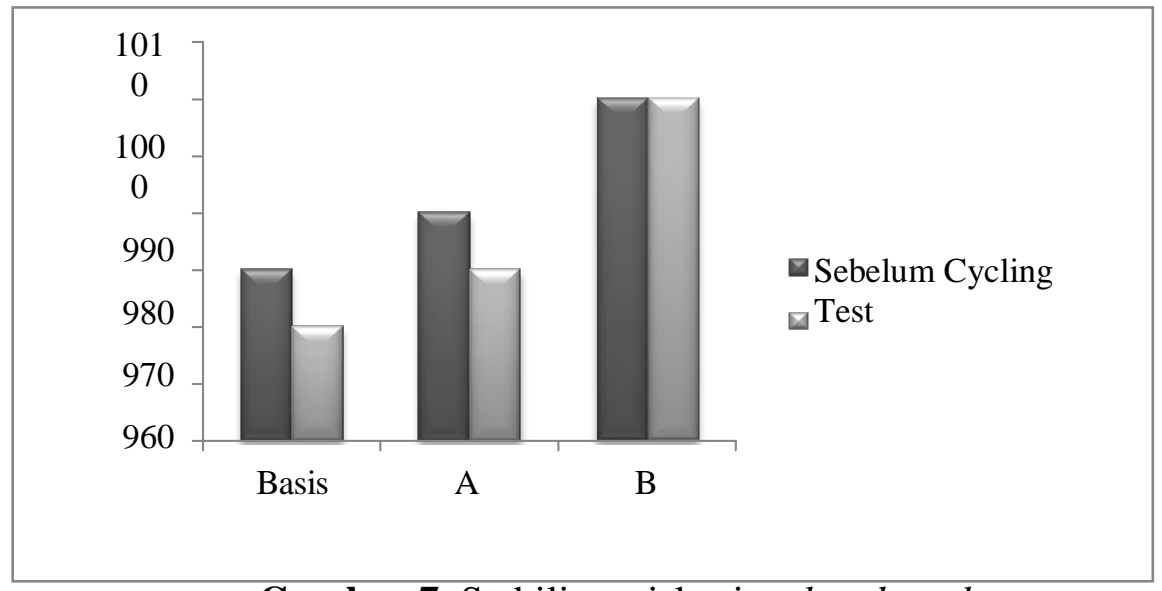

Gambar 7. Stabilitas viskositas hand wash

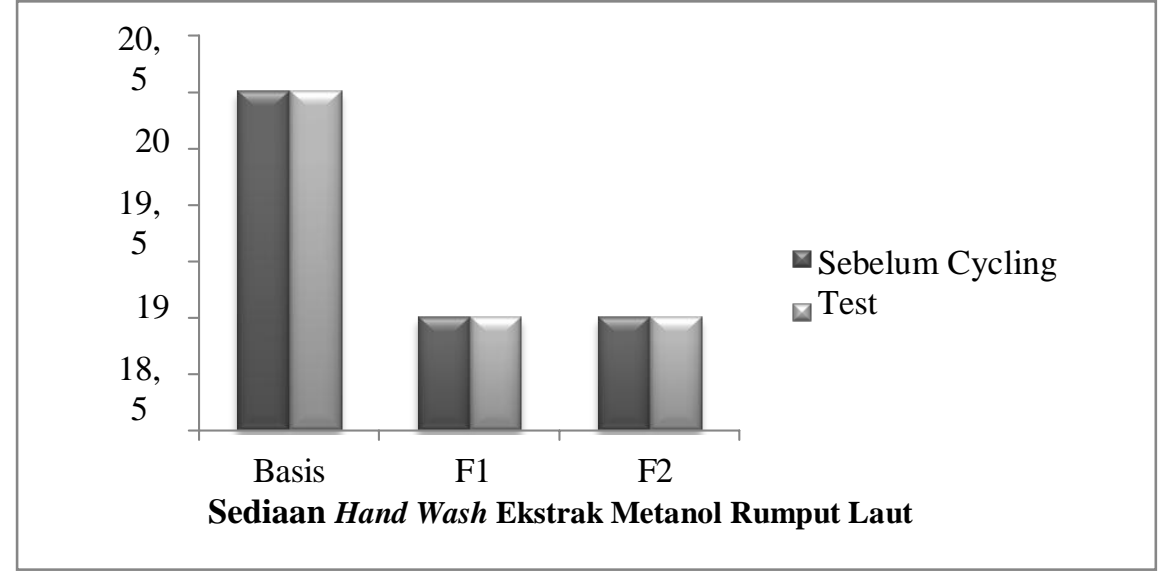

Gambar 8. Stabilitas kemampuan membentuk busa hand wash 


\section{PEMBAHASAN}

Pengujian aktivitas antibakteri ekstrak metanol E. spinosum dilakukan terhadap bakteri Gram positif (S. aureus) dan Gram negatif (E. coli). Bakteri tersebut merupakan flora normal pada kulit dan penyebab umum timbulnya penyakit.

Uji pendahuluan yaitu penentuan Kadar Hambat Minimum (KHM) dan Kadar Bunuh Minimum (KBM) bertujuan mengetahui konsentrasi terkecil dari ekstrak yang mampu menghambat dan membunuh bakteri. Penentuan nilai KHM dan KBM dilakukan dengan metode dilusi cair berdasarkan kejernihan media NB pada tabung uji. Pengujian dikaukan dengan tiga replikasi. Media yang keruh menunjukkan adanya pertumbuhan bakteri sedangkan media yang jernih berarti tidak ada pertumbuhan bakteri. Hasil uji aktivitas antibakteri ekstrak dengan metode dilusi cair dapat dilihat pada Tabel 2.

Berdasarkan hasil pengujian diperoleh konsentrasi ekstrak 4\% dan kontrol negatif tampak keruh. Sedangkan konsentrasi ekstrak 6\%, 8\%, 10\%, dan kontrol positif namun tampak jernih.

Selanjutnya dilakukan uji penegasan KHM dan KBM dengan metode dilusi padat dengan tujuan memastikan media NB jernih yang terbentuk sudah dapat menghambat dan membunuh bakteri. KHM ditunjukkan oleh adanya pertumbuhan bakteri di sekitar goresan bakteri pada media NA. Sedangkan KBM ditunjukkan oleh tidak adanya pertumbuhan bakteri di sekitar goresan Hasil uji aktivitas antibakteri ekstrak dengan metode dilusi padat dapat dilihat pada Gambar 1 dan 2.

Hasil pengamatan menunjukkan ekstrak metanol E. spinosum dapat menghambat dan membunuh bakteri $S$. aureus dan E. coli. Konsentrasi 6\% media NB tampak jernih namun terdapat pertumbuhan bakteri pada media NA sehingga konsentrasi $6 \%$ dinyatakan sebagai nilai KHM untuk ekstrak metanol rumput laut E. spinosum.

Pada konsentrasi 8\% media NB tampak jernih dan tidak terdapat pertumbuhan bakteri pada media NA sehingga konsentrasi $8 \%$ dinyatakan sebagai nilai KBM untuk ekstrak metanol rumput laut $E$. spinosum. Begitu pula pada konsentrasi $10 \%$ dan kontrol positif, media tampak jernih baik pada metode dilusi cair maupun uji penegasan denga metode dilusipadat.

Aktivitas antibakteri ekstrak disebabkan oleh metabolit sekunder yang terdapat pada ekstrak tersebut antara lain flavonoid, alkaloid, triterpenoid dan polifenol (Al-Haj dkk., 2009).

Senyawa golongan alkaloid bekerja dengan cara mengganggu komponen penyusun peptidoglikan pada sel bakteri, sehingga lapisan dinding sel tidak terbentuk secara utuh dan menyebabkan kematian sel (Safitri, 2017). Senyawa golongan flavonoid dalam rmpur laut Eucheuma spinosum di antaranya 2,7naphthyridine dan 2-phenylethylamine (Maria, 2016) memiliki mekanisme kerja sebagai antibakteri dengan cara membentuk senyawa kompleks bersama protein ekstraseluler sehingga dapat merusak membran sel bakteri dan kemudian diikuti dengan keluarnya senyawa intraseluler yang berakibat pada kematian sel bakteri (Nuria dkk., 2009).

Senyawa golongan triterpenoid dalam rumput laut yaitu cartilagineol, obtusol dan elatol (Maria, 2016) bekerja sebagai antibakteri dengan cara bereaksi 
dengan porin (protein transmembran) pada membran luar dinding sel bakteri, kemudian membentuk ikatan polimer yang mengakibatkan rusaknya porin. Rusaknya porin yang merupakan pintu keluar masuknya senyawa akan mengurangi permeabilitas membran sel bakteri dan sel bakteri kekurangan nutrisi sehingga pertumbuhannya terhambat atau mati (Cowan, 1999).

Polifenol merupakan senyawa organik yang aktif menghambat beberapa bakteri. Salah satu contoh golongan senyawa polifenol adalah tanin. Polifenol menghambat pertumbuhan bakteri dengan cara menghambat aktivitas enzim protease, menghambat enzim pada protein transpor selubung sel bakteri dan destruksi atau inaktivasi fungsi materi genetik (Masduki, 1996). Biasanya aktivitas antibakteri pada bahan alam laut disebabkan oleh adanya phloroglucinol, eckol and dieckol (Suleria, 2016). Selanjutnya ekstrak dengan konsentrasi yaitu 8\% dan 10\% diformulasi menjadi sediaan hand wash. Salah satu faktor terpenting dari keberhasilan pembuatan sabun cair adalah pencampuran eksipien menghasilkan cairan yang homogen, $\mathrm{pH}$ di bawah 10, tidak berubah oleh pengaruh udara dan suhu, serta mengiritasi kulit. Eksipien yang digunakan pada formulasi ini adalah natrium lauril sulfat, metil paraben, Na-CMC, gliserin, dinatrium- EDTA, minyak lemon, dan sunset yellow.

Pembuatan hand wash dimulai dengan melarutkan natrium lauril sulfat dalam air suling. Natrium lauril sulfat $1 \%$ dapat digunakan pada sediaan topikal sebagai pembersih dan pembentuk busa (Rowe dkk., 2009). Konsentrasi natrium lauril sulfat yang digunakan yaitu 3\% untuk mendapatkan busa yang lebih baik.
Menurut Hardian dkk (2014), sediaan sabun padat dengan 3\% natrium lauril sulfat tidak menyebabkan iritasi pada 20 orang panelis. Menurut Apgar (2010) sabun mandi cair dengan 5\% natrium lauril sulfat tidak mengiritasi kulit. Namun konsentasri $10 \%$ dapat menyebabkan iritasi sedang (Dewantara dkk,2012).

Sediaan hand wash selanjutnya diuji aktivitas antibakterinya terhadap $S$. aureus dan E. coli.Metode yang digunakan pada pengujian ini sama seperti pada pengujian aktivitas antibakteri ekstrak yaitu metode dilusi cair pada media NB dan metode dilusi padat pada media NA. Hasil uji aktivitas antibakteri hand wash dengan metode dilusi cair dapat dilihat pada tabel 3.

Berdasarkan hasil pengujian terhadap bakteri $S$. aureus semua media tampak jernih. Sedangkan hasil pengujian terhadap bakteri E. coli, semua media tampak jernih, kecuali media untuk Ktampak keruh.

Selanjutnya dilakukan uji penegasan dengan metode dilusi padat dan hasilnya dapat dilihat pada Gambar 3 dan 4. Hasil pengamatan menunjukkan bahwa basis hand wash dapat menghambat bakteri $S$. aureus tetapi tidak menghambat $E$. coli. yang ditandai dengan media yang jernih pada tabung uji tetapi pada uji penegasan terdapat pertumbuhan bakteri. Aktivitas penghambatan tersebut disebabkan oleh natrium lauril sulfat yang bersifat bakteriostatik terhadap bakteri Gram positif (Rowe dkk, 2009).

Formula A dan B dapat membunuh bakteri S. aureus dan E. coli yang ditandai dengan media yang jernih pada tabung uji dan tidak ada pertumbuhan bakteri pada uji penegasan. Serupa dengan K+ (Sabun 
merek L) juga menunjukkan tidak adanya pertumbuhan bakteri.

Selanjutnya dilakukan uji stabilitas sediaan hand wash untuk mengetahui pengaruh penyimpanan dan distribusi produk melalui parameter fisik meliputi organoleptik, nilai $\mathrm{pH}$, viskoitas, dan kemampuan membentuk busa. Salah satu metode uji stablitas adalah cycling test.

Metode cycling test dilakukan untuk mempercepat kondisi penyimpanan sediaan dengan melihat ada tidaknya perubahan yang biasanya terjadi pada kondisi normal dengan cara menyimpan sediaan hand wash pada suhu $4^{\circ} \mathrm{C}$ dan $40^{\circ} \mathrm{C}$ masing-masing selama 24 jam yang dihitung sebagai 1 siklus. Hasil pengamatan terhadap stabilitas organoleptik dapat dilihat pada Tabel 7.

Pengukuran $\mathrm{pH}$ dilakukan untuk mengetahui keasaman hand wash guna menjamin sediaan tidak mengiritasi kulit. Sediaan dengan $\mathrm{pH}$ rendah akan menimbulkan iritasi pada kulit dan jika $\mathrm{pH}$ tinggi maka akan menyebabkan kulit bersisik (Budiman, 2008). Menurut standar SNI nomor 06-4085-1996, nilai pH untuk sabun cair yaitu 6-8.

Hasil uji pH dapat dilihat pada Gambar 6. Nilai pH tertinggi adalah K(basis tanpa ekstrak). Sedangkan nilai $\mathrm{pH}$ terendah adalah formula B(ekstrak 10\%). Setelah cycling test semua sediaan hand wash mengalami penurunan nilai $\mathrm{pH}$. Hal ini disebabkan oleh proses hidrolisis karena peningkatan suhu. Namun nilai pH masih berada dalam rentang yang dipersyaratkan oleh SNI.

Selanjutnya dilakukan pengukuran viskositas. Viskositas merupakan pernyataan tahanan dari suatu cairan untuk mengalir. Viskositas sangat penting dalam formulasi sediaan cair dan semipadat karena menentukan sifat campuran dan sifat alirnya, baik pada saat diproduksi, dimasukkan ke dalam kemasan, serta sifatsifat penting pada saat pemakaian meliputi konsistensi, daya sebar, dan kelembaban.

Semakin tinggi viskositas suatu cairan maka tahanan untuk mengalir semakin besar. Akibatnya sediaan sulit dikeluarkan dari wadah sehingga mengurangi kenyamanan saat digunakan. Apabila viskositasnya rendah maka maka sediaan menjadi mudah mengalir sehingga sulit diaplikasikan oleh pengguna. Viskositas dari suatu sediaan juga akan mempengaruhi stabilitas fisik (Paye dkk., 2001). Menurut standar SNI nomor 064085-1996, nilai viskositas untuk sabun cair yaitu 500-20.000cP.

Hasil uji dapat dilihat pada Gambar 7. Nilai viskositas tertinggi adalah formula B(ekstrak 10\%). Sedangkan nilai $\mathrm{pH}$ terendah adalah K- (basis tanpa ekstrak). Setelah cycling test formula Btidak mengalami perubahan, sedangkan formula A(ekstrak 8\%) dan K- mengalami penurunan viskositas. Hal ini dapat disebabkan oleh kelembaban udara dakam kemasan dan ruang penyimpanan. Kemasan yang tidak kedap menyebabkan sediaan menyerap uap air dari luar kemsan sehingga menambah volume air dalam sediaan. Namun viskositas masih berada dalam rentang yang dipersyaratkan oleh SNI.

Selanjutnya dilakukan uji kemampuan membentuk busa dengan mengukur tinggi busa yang dihasilkan dari sediaan hand wash. Kebanyakan pengguna menganggap busa yang melimpah mampu membersihkan kotoran dengan baik. Stabilitas membentuk busa akan mempengaruhi kepuasan pengguna. kemampuan Menurut Harry (1973) tinggi 
busa untuk sabun cair yang baik yaitu 13$220 \mathrm{~mm}$.

Hasil uji dapat dilihat pada Gambar 8. Kemampuan membentuk busa tertinggi adalah K- (basis tanpa ekstrak). Sedangkan formula A dan B kemampuannya sama. Setelah cycling test tidak terjadi perubahan. Stabilitas pembentukan busa

\section{SIMPULAN}

Disimpulkan bahwa ekstrak metanol rumput laut $E$. spinosum dapat diformulasi menjadi sediaan hand wash antibakteri dengan konsentrasi 8\% dan 10\%.

\section{SARAN}

Perlu dilakukan uji hedonik dan uji iritasi.

\section{DAFTAR PUSTAKA}

Al-Haj, N. A., Nurmas I. M., Mariana N. S., Habsah M., Charles S. V., dan Zamberi S., 2009, Antibacterial Activity in Marine Algae Eucheuma denticulatum Against Staphylococcus aureus and Streptococcus pyogenes, Journal of Biological Science, 4(4):519-524.

Alea E.T.O. dan Melbert C.S, 2019, Antibacterial Potential of Liquid Hand Soap with Piper aduncum Leaf Extract, International Journal of Life Sciences, 7(1): 1-9

Anonim, 2014, Kebijakan dan Politik Maritim, www.bumn.go.id, diakses pada bulan Agustus 2014.

Apgar, S., 2010, Formulasi Sabun Mandi Cair yang Mengandung Gel Lidah Buaya (Aloe vera (L.) Webb) dengan Basis Virgin Coconut Oil (VCO), Skripsi, Fakultas MIPA, Universitas IslamBandung.
Budiman, M. H., 2008, Uji Stabilitas Fisik dan Aktivitas Antioksidan Sediaan Krim yang Mengandung Ekstrak Kering Tomat (Solanum lycopersicum $\quad$ L.), $\quad$ Skripsi, Universitas Indonesia.

Cahyani, Novita M. E., 2014, Daun Kemangi (Ocinum cannum) Sebagai Alternatif Pembuatan Handsanitizier, Jurnal Kesehatan Masyarakat, 9(2): 136-142.

Coremap, 2001, CRITC Report: Base Line Study Wakatobi Sulawesi Tenggara, Coremap, Jakarta.

Cowan, M., 1999, Plant Product as Antimicrobial Agent, Clinical Microbiology Reviews, 12 (4): 564582.

Deiner, F., 2008, Formulasi Bath Gel Bengkuang dan Madu, Skripsi, Institut Pertanian Bogor.

Dewantara, I., Prasetia, I., Jemmy A., Putri, N., Arsana. D., dan Prabayanti, N., 2012, Uji Eritema Dan Edema Secara In Vivo Pada Natrium Lauril Sulfat 10\%, Fakultas MIPA, Universitas Udayana.

Fatisa, Y., 2013, Daya Antibakteri Estrak Kulit dan Biji Buah Pulasan (Nephelium mutabile) terhadap Staphylococcus aureus dan Escherichia coli Secara In Vitro, Jurnal Peternakan, 10(1):31-38.

Hardian, K., Akhyar A., dan Yusmarini Y., 2014, Evaluasi Mutu Sabun Padat Transparan dari Minyak Goreng Bekas dengan Penambahan SLS (Sodium Lauryl Sulfate) dan Sukrosa, Jurnal Online Mahasiswa Faperta Universitas Riau,1(2): 1-11.

Harry, R.G., 1973, Harry's Cosmeticology, Leonard Hill Books An Intertext Publ, London. 
Joy, Jyothi M., AVS Praveen K., S Mohanalakshmi, dan S Prathyusha, 2012, Formulation and Evaluation of Poly Herbal Hand Wash, International Journal of Pharmacy, 2(2): 39-43.Maria J.P., Elena F., dan Hermina D., 2016, Antimicrobial Action of Compounds from Marine Seaweed, Marine Drug, 14 (3): 1-38.

Masduki, I, 1996, Efek antibakteri ekstrak biji pinang (Areca catechu) terhadap S. aureus dan E.coli, Cermin Dunia Kedokteran, 21(4), 23-24.

Nuria, M.C., Faizatun, Sumantri, 2009, Uji Antibakteri Ekstrak Etanol Daun Jarak Pagar (Jatropha cuircas L.)terhadap Bakteri Staphylococcus aureus ATCC 25923, Escherichia coli ATCC 25922 dan Salmonella typhi ATCC 1408, Jurnal IlmuilmuPertanian.5:26-37.Paju, N., Pulina V. Y. Y., Npvel K., 2013, Uji Efektivitas Salep Ekstrak Daun Binahong (Anredera cordifolia (Ten.) Steenis) pada Kelinci (Oryrolagus cuniculuc) yang Terinfeksi Bakteri Staphylococcus aureus, Pharmacon : Jurnal Ilmiah Farmasi, 2(1): 51-61.

Pal, Prince K., Palash M., Ravi K., Rajesh S., Harjeet S., Biresh K.S., 2015, Formulation and Evaluation of Hand Wash of Vitex Negundo, World Journal of Pharmacy and Pharmaceutical Sciences, 4(11): 1488- 1492.

Patil, S.S., Yuvraj J.M., dan Shrinivas .M., 2015, Formulation and Evaluation of Herbal Hand wash, International Journal of Universal Pharmacy and Bio Sciences, 4(2): 30-33.

Paye, M., Barel, A.O dan Maibach, H.I., 2001, HandBook of Cosmetic
Science and Technology, Marcel Dekker Inc, NewYork.

Poolman, J.T. and Annaliesa S.A., 2018, Escherichia coli and Staphylococcus aureus: Leading Bacterial Pathogens of Healthcare Associated Infections and Bacteremia in Older-Age Populations, Expert Review of Vaccines, 17 (7): 1-12Rowe, R.C, Paul J.S, dan Marian, 2009. Handbook Of Pharmaceutical Science $6^{\text {th }}$ Edition. Pharmaceutical Press, USA.Safitri, A., Arie S., Anna R., dan Sutrisno, Antibacterial Activity and Phytochemical Analysis of Edible Seaweed Eucheuma spinosum Againts Staphylococcus aureus, 2018, J. Pures App. Chem. Res., 7 (3): 308315.

Safitri, L., Tri E.S., Puguh S., 2017, Evaluasi Aktivitas Antimikroba (Streptococcus agalactiae) Menggunakan Ekstrak Buah Mahkota Buah (Phaleria macrocarpa L.) dengan Pelarut yang Berbeda, Jurnal Ilmu dan Teknologi Hasil Ternak, 12 (1): 8-15

Siregar, A.F, Agus S., dan Delianis P., 2012, Potensi Antibakteri Ekstrak Rumput Laut terhadap Bakteri Penyakit Kulit Pseudomonas aeruginosa, Staphylococcus epidermidis, dan Micrococcus luteus, Journal of Marine Research. 1 (2):152-160.

Suleria, H.A.R. Osborne, Masci P., Gobe G. Marine-Based Food and Supplement Industries, 2015, Marine Drug, 13 (1): 1-38.

WHO, 2006, WHO Guidelines on Hand Hygiene in Health Care (Advanced 
